University of Rhode Island

DigitalCommons@URI

Open Access Master's Theses

1990

\title{
The Relationship Between Locus of Control, Gender and Field of Study Among Graduate Students at the University of Rhode Island
}

Mary Fetherston

University of Rhode Island

Follow this and additional works at: https://digitalcommons.uri.edu/theses

\section{Recommended Citation}

Fetherston, Mary, "The Relationship Between Locus of Control, Gender and Field of Study Among Graduate Students at the University of Rhode Island" (1990). Open Access Master's Theses. Paper 1659. https://digitalcommons.uri.edu/theses/1659

This Thesis is brought to you for free and open access by DigitalCommons@URI. It has been accepted for inclusion in Open Access Master's Theses by an authorized administrator of DigitalCommons@URI. For more information, please contact digitalcommons-group@uri.edu. 
THE RELATIONSHIP BETWEEN

LOCUS OF CONTROL, GENDER AND FIELD OF STUDY

AMONG GRADUATE STUDENTS

AT THE UNIVERSITY OF RHODE ISLAND

BY

MARY FETHERSTON

A THESIS SUBMITTED IN PARTIAL FULFILLMENT OF THE REQUIREMENTS FOR THE DEGREE OF

MASTER OF ARTS

IN

EDUCATION

UNIVERSITY OF RHODE ISLAND

1990

$242330 \%$ 


\section{ABSTRACT}

The purpose of this study was to examine the effects of both field of study and gender on locus of control orientation among graduate students at the University of Rhode Island at Kingston.

This study solicited participation from graduate students enrolled at the University of Rhode Island, spring semester, 1990 excluding those enrolled in the Graduate School of Oceanography, School of Business and in courses offered by the Director of the College of Continuing Education (CCE) Special Programs Division were excluded from the study. A total of 804 graduate students returned the two surveys which were used to gather data. Data on locus of control orfentation was measured by the Reid-Ware Locus of Control Scale. Personal data concerning gender and field of study was gathered on a separate survey. Graduate students were divided into six academic disciplines based upon indicated field of study (Math and Sciences, Human Sciences, Fine Arts, Business, Health, and Natural Resources). Graduate students were compared on total and three subscale scores- Fatalism, Self Control, and Social Systems Control- of the locus of control construct.

It was concluded that significant differences exist between genders only on the Self Control subscale; no significant differences were found on Fatalism, Social Systems Control or on the total score. Significant differences were not found on the locus of control construct between academic disciplines. Additional findings indicate that the older students were significantly different on the Social 
Systems Control subscale than younger students. Also, foreign students were significantly different than the indigenous students on the total score and two subscales (Fatalism and Social Systems Control). 


\section{ACKNOWLEDGEMENTS}

Appreciation is expressed to members of my committee who have provided assistance, support and advice in the preparation and completion of this thesis. To my advisor, John Boulmetis, I express my thanks for his help in keeping me on the right path and for his support before and during the research project. To William Croasdale, I express my gratitude for his direction and words of encouragement. To Jerome Schaffran, I express my appreciation for his availability and constructive suggestions. To Phillip Clark, I express my thanks for his words of support and wisdom that kept me moving ahead. To Joseph Rossi, I express my gratitude for his counsel and enthusiasm; making those final steps that much easier.

For their invaluable assistance, I would like to thank both Mackie Robinson and Marilyn Lombari. Both provided word processing knowledge, words of advice and helping hands when I needed them. To Kristen Ryan and Johnny Boulmetis, I extend special thanks for giving up their valuable free time to help record the data.

For his love, support and willingness to take on extra duties, I express unbounded gratitude to my husband of seven years, Thomas Nelson Fetherston. I express my deepest appreciation to a dear friend, Cheryl Cadwell, for her enthusiasm, advice, and willingness to collate, fold, and sort over fifteen hundred surveys, as well as commiserate when appropriate. 
Page

Table of Contents

List of Tables

$\mathrm{v}$

vi

$1-8$

1. Introduction

Background of the problem

Statement of the problem

Purpose of the study

Theoretical assumptions

Research hypotheses

Importance of the study

Definition of terms

2. Review of the Literature

Locus of control construct

Achievement and success

Field of study

Gender differences

Summary

3. Research Methods

Research approach

Research design

Null hypotheses

Selection of subjects

Instrumentation

Data collection procedure

Data analysis procedure

Methodolical assumptions

Limitations of the study

4. Results

Description of subjects

Discussion of findings

Additional significant findings

5. Summary, Conclusions \&

Recommendations

Summary

Discussion

Conclusions

Implications

Recommendations for further research

References Cited

Appendices

Bibliography
3

4

5

5

6

6

8

9-15

9

11

13

13

15

16-24

16

16

17

18

19

20

20

22

23

25-47

25

33

38

48-56

48

49

52

53

54

57-60

61- 68

69-73 


\section{LIST OF TABLES}

Table

Page

1 Delineation of Surveys by Discipline \&

Field of Study

2 Delineation of Subjects by Gender

26-27

29

3 Delineation of Subjects by Gender \& Field of Study

4. Delineation of Total Population by Gender 29

5 Delineation of Sample by Age

6 Delineation of Total Population by Age 31

7 Frequency Distribution by Degree 32

8 Frequency Distribution by Degree \& Gender 32

9 Frequency Distribution by Gender \& Degree 32

10 ANOVA Results of Hypothesis 1

11 ANOVA Results of Hypothesis 2A 35

12 ANOVA Results of Hypothesis 2b

13 ANOVA Results of Hypothesis 2c 37

14 ANOVA Results of Hypothesis 2d 37

15 ANOVA Results of Field of Study on the Social Systems Control Subscale

40

16 Comparison of Fields of Study on the Social Systems Subscale

17 ANOVA Results of Age Category Compared to the Locus of Control Total Score

18 ANOVA Results of Age Category Compared to the Social Systems Control Subscale

19 Comparison of Age Categories on the Social Systems Control Subscale

20 ANOVA Results of Foreign vs. Indigenous Students on Locus of Control Total Score

21 ANOVA Results of Foreign vs. Indigenous Students on Social Systems Control Subscale

22 ANOVA Results of Foreign vs. Indigenous Students on Fatalism Subscale

23 ANOVA Results of Foreign vs. Indigenous Students on Self Control Subscale

24 Sample Population Compared to Normative Sample and Stack Sample 


\section{CHAPTER 1 \\ INTRODUCTION}

In 1987, a paper which reviewed all forms of research with a graduate student population was presented at the annual meeting of the Association for the Study of Higher Education. Citing waning interest in the graduate student population after its peak enrollment in the mid-1970s, the paper examined the paucity of research conducted in the years 1976-1987. Although this review of research focused on studies published in 20 academic journals, a computer search of ERIC, Dissertations Abstracts International, and Psychological Abstracts, it also documented the scarcity of research being conducted with this population.

Although studies with this population have been diverse, they can be categorized as follows: matriculation; predicting success/ performance; gender differences, assistantships, standardized testing, career employment; minorities; stress and anxiety, attitudes toward research; impact of marriage and family; and attrition/retention. The majority of these studies focused on the categories of matriculation (including recruitment, admissions and student characteristics) and prediction of success. Cutting across these categories were sixteen studies dealing with the locus of control construct and its independent/dependent relationship with other variables.

The original research on the locus of control construct was completed by Julian Rotter in 1954. He defined locus of control as a continuum affecting a person's perception of behavioral reinforcement. 
[The] effect of a reinforcement following some behavior on the part of a human subject, in other words, is not a simple stamping-in process but depends upon whether or not the person perceives a causal relationship between his own behavior and the reward. When a reinforcement is perceived by the subject as following some action of his own but not being entirely contingent upon his action, then, in our culture, it is typically perceived as the result of luck, chance, fate as under the control of powerful others, or as unpredictable because of the great complexity of the forces surrounding him--when the event is interpreted in this way by the individual, we have labeled this a belief in external control. If the person perceives that the event is contingent upon his own behavior or his own relatively permanent characteristics, we have termed this a belief in internal control. (Rotter, 1966)

A person who believes that reinforcement is independent of his/her personal actions is on the external end of the continuum. If a person believes that rewards are contingent upon his/her personal actions, then he/she is on the internal side of the scale.

Research indicates that high achievement is related to internal locus of control among varying groups. Locus of control has been shown to differentiate between success and failure at lower levels of education (Seeman, 1963; Norwicki \& Walker, 1973). Both Phares (1976) and Otter (1977) found that locus of control measures were a good predictor of degree attainment in graduate students. Although more longitudinal studies which could directly correlate locus of control and success in graduate school have not been conducted, other studies have demonstrated that more internally oriented persons value self-respect, wisdom, freedom, a sense of accomplishment and intellectualism more than those 
persons with an external orientation (Linder, 1985). In addition, locus of control has also been correlated with development of purpose, educational maturity, and career maturity in graduate students (Barrow, 1982). This research will focus on the issue of the relationship between field of study, gender and locus of control.

\section{Background of the Problem}

As previously stated, research with the graduate population has suffered a decline despite the definite need for more information on both successful recruiting practices and factors attributing to matriculation.

Graduate education as an entity is perceived to be far behind the undergraduate in establishing a body of knowledge regarding admission characteristics and activities of students; methods of recruitment; utilization of available technology; centralization of effort and funding; enrollment management and modeling (Turcotte, 1983, page 26).

Within the spectrum of graduate education, women traditionally have been underrepresented, but recently the number of women earning Master's degrees has almost equaled that of men (ASHE 1987). Within doctoral programs the number of women enrolled has increased, but unfortunately it is still far below the male total (Roemer, 1983). Research dealing with gender in the graduate population has tended to focus on matriculation (Berg and Ferber, 1983; Roemer, 1983) and characteristics rather than specific values/ attributes that might be a factor in educational success/achievement or even the pursuit of a graduate degree. 


\section{Statement of the Problem}

Although research dealing with the locus of control variable can be categorized as either single or multi-discipline, the majority of research dealing with graduate student populations has been limited to a single discipline (Linder, 1985; Madden and Carli, 1981). Relatively few studies have dealt with the variable across discipline areas (Doody, 1980; Barrow, 1982).

Within the single discipline category, the studies focusing on differences in locus of control as related to gender have yielded varied results. A study of 731 graduate students attending the Virginia Commonwealth University during the 1983-86 academic years indicated that males were more internally oriented than females (Linder, 1987). Linder also reported the same findings in a smaller study (413 students) at the same university in 1985. Conversely, a study at the University of Georgia found that 131 students varied on locus of control in relation to age and employment status but not as to race or gender (Cartledge, 1985). Additionally, Doody (1980) found that race and field of study were more important determinants of internal-external orientation than gender among 264 interns in the Teacher Corps program from 39 states.

Further research is needed to examine differences across a greater range of disciplines and explore the differences in results involving the gender variable. 


\section{Purpose of the Study}

The purpose of this study was to investigate the relationship between locus of control, gender and field of study among graduate students and to explore areas of ambiguity raised by earlier research. The following questions acted as guidance:

1. What is the relationship between gender and locus of control?

2. What is the relationship between field of study and locus of control?

3. Is gender a greater factor related to locus of control than field of study?

4. If locus of control is divided into the three subscales (self-control, social systems control and fatalism), are the differences between gender or field of study greater on any single scale?

5. Are there other factors related to locus of control?

\section{Theoretical Assumptions}

In order to conduct this research, a number of theoretical assumptions were made. First, that locus of control is a construct that can be measured reliably. It is not a dichotomy, but a conceptual continuum and individuals will place somewhere along the continuum; either more external or internal depending upon their personal beliefs and stage of development. Second, that within a given culture, certain differences exist in the acculturation of male and females. Within each gender a certain degree of homogeneity of development exists so that males and females can be studied 
separately. Third, that individuals within each field of study share common interests and that these persons can be grouped together for research purposes. In both the second and third assumption, it is relevant that college students, and therefore graduate students, are more homogeneous in. relevant ways than the culture from which they are drawn (Plant and Telford, 1966).

\section{Research Hypotheses}

The research hypotheses were:

1. Hypothesis 1: There is a relationship between locus-ofcontrol orientation and field of study of graduate students.

2. Hypothesis 2: There is a relationship between gender and locus-of-control orientation of graduate students.

3. Hypothesis 3: Either gender or field of study will be a more dominant variable affecting locus-of-control; both will not exert an equal effect.

\section{IMPORTANCE OF THE STUDY}

Studies have revealed that perceived personal control (internal orientation) can be positively correlated to satisfaction with the graduate school experience (Madden and Carli, 1981). There is a possibility of maximizing achievement behavior by providing students with instruction and feedback that would encourage them to make internal attributions for success and lack of effort attributions for failure, thus enhancing their internal orientation (Cartledge, 1985). Therefore, the graduate school experience and students' subsequent performance would be enhanced by arranging 
environmental factors so that the student will view failure/success as contingent upon his/her own efforts, thereby increasing his/her internal orientation (Guterriez, 1982).

Lozoff (1976) discussed the roles that all departments can play in developing a sense of purpose, personal identity, and professionalism in their graduate students. It is important that faculty be cognizant of inherent differences among the students under its purview in order to foster their professional development. This commitment to student development is manifested in the application of information on student characteristics into one's teaching style and role (Allen, 1977). The results of this study delineate differences among graduate students at the University of Rhode Island; this information could increase the effectiveness of the faculty who teach and counsel these students.

This study will be unique since it attempts to measure the relationship among the dimensions of field of study choice, gender and locus of control across a spectrum of more than thirty disciplines. Prior research has focused on one or more disciplines in a limited sample, or one discipline across a number of college and university campuses. The largest range of disciplines in locus of control research with graduate students was conducted at the University of Maine at Orono (Barrow, 1982), but eliminated all engineering and science fields and any students under 22 or over 45 years of age. In addition, due to the large base of graduate students at the University of Rhode Island, the sample size (1692) available for this research was larger than the norm in other locus of control studies. 


\section{DEFINITION OF TERMS}

Locus of Control: A continuum affecting a person's perception of behavioral reinforcement within his/her own environment (Rotter, 1954).

Internals (persons displaying an internal locus-of-control): Individuals who believe that reinforcements in their environment are achieved as a result of their own efforts.

Externals (persons displaying an external locus-of-control): Individuals who believe that reinforcements in their environment occur based upon luck, fate or the control of more powerful others.

Graduate Students: Students who have matriculated from an accredited university or college and are now seeking either a certificate of study, Master's or doctoral degree and are enrolled at the university either full- or part-time.

Foreign Students: Students whose acculturation occurred in a foreign setting (other than U.S.), whether or not they have become naturalized citizens of the U.S.

Field of Study: The chosen subject of a graduate student for their educational pursuit, either a certificate of study, Master's or doctoral degree. 


\section{CHAPTER 2 \\ REVIEW OF THE LITERATURE}

The review of literature has been divided into four sections. In the first section, theories related to the construct of locus of control are discussed. In the second section, the relevant literature dealing with achievement and success and the locus of control construct is summarized. In the third section, research on differences between individuals across fields of study is reviewed. In the fourth section, the research conducted on gender differences and their relationship to locus of control are summarized.

\section{Locus of Control Construct}

Social learning theory postulates that the majority of all behaviors are learned in a social setting. Both expectancy and reinforcement concerning the learned behaviors are contingent upon the cultural biases present in the environment, i.e. rewards are given for socially acceptable behaviors and punishment may be administered for behavior that is considered inappropriate. Thus expectancy, reinforcement and learning are interrelated.

The effects of behavioral reinforcement depend in varying extent on whether the individual perceives reinforcement as being contingent upon his or her own behavior, or independent of it. Studies have shown that those individuals who possess a belief in personal control of reinforcements tend to be more perceptive of those environmental variables which may yield information relevant to their future behavior (Rotter 1954, 1966). 
Rotter proposed the construct of locus of control to describe the causal relationship between reinforcement and personal actions. Individuals who felt that reinforcements in their environment were triggered by their personal actions were on one side (internal) of the construct continuum. These persons were more likely to value success and take action to improve their quality of life (cerebral or physical). On the other side of the continuum (external), were the individuals who believed that reinforcements in the environment were not subject to their control. These individuals felt that fate, luck, chance or more powerful others could manipulate environmental rewards that they desired.

It is important to note that the idea of internal-external locus of control was modified by Lefcourt (1976) so that the perception of causal relationships in the environment is only half of the construct. Individuals must also be able to interpret these perceptions; using this interpretation as the guidance for future behaviors.

Research in the past two decades has explored the relationship between locus of control and other constructs or behaviors. Several studies have indicated that internals have a statistically significant advantage over externals with regard to information acquisition and assimilation and to attentive abilities (Phares, 1968; Seeman 1963). When comparing value acquisition and locus of control, it has been shown that more internally oriented individuals valued self-respect, wisdom, freedom, a sense of accomplishment and intellectualism. Externally oriented persons valued family security, a comfortable life, and cheerfulness (Linder et al, 1985). 
Most of this research has focused on the ability of internally oriented individuals to engage in more goal-directed activity than their external counterparts. Externally oriented persons spend more time in emotional or non-goal directed behaviors. Externals often fail to see that a relationship does exist between their actions and the reinforcement that follows or the lack thereof (MacDonald, 1973).

The majority of research on the locus of control construct has treated it as a one-dimensional concern. A minority of the research has suggested that the construct may actually be multi-dimensional (Mirels, 1970; Levenson, 1972; Reid and Ware, 1973, 1974). In a research study with an undergraduate population, Mirels (1970) postulated that two subscales were present, luck and belief in one's own innate abilities. Using Rotter's internal-external instrument, he factor analyzed the twenty three valid questions, having discarded the six buffer items, and found the two separate dimensions.

Reid and Ware (1973) expanded on Mirels' research using a multiple regression model and identified and measured two independent dimensions of fatalism and social systems control. In a later study (1974), Reid and Ware factored out a third subscale, selfcontrol. Belief in self control differs from the other two factors, fatalism (belief in luck) and social systems control (belief in more powerful others), in the perception that personal action has a direct effect on environmental rewards.

\section{Achievement and Success}

Although much research has been conducted with regard to success in scholastic endeavors and locus of control, most of the 
studies have tended to focus on scholastic achievement in grades one through twelve (Baron and Ganz, 1972; Norwicki and Walker 1973) or on the undergraduate level (Hazen, 1980; Lombardo and Fantasia, 1978; Phares, 1968; Rotter and Mulry, 1965; Weaver, 1976). Hazen (1980) found that locus of control was a strong predictor of achievement with an undergraduate population. On the graduate level, a longitudinal study investigating the relationship between grade point average and degree attainment in males revealed a strong positive correlation between degree attainment and an internal locus of control. Locus of control was found to be a greater predictor of degree attainment than grade point average (Otten, 1977).

Internals (people who have an internal locus of control) have also been found to score higher on the flexibility and originality portions of the Unusual Uses subtest of the Torrance Tests of Creative Thinking (Glover and Sautter, 1976). While flexibility and originality could be vital in the creative thinking portion of problem solving, internals failed to perform significantly better on other portions of the test. In the research with juvenile prisoners in a reformatory (Seeman,1963), results revealed a substantial correlation occured between internal orientation and the amount of parole material recalled . Acquisition of information concerning immediate reformatory situation and long-range prospects did not demonstrate a correlation with the internal-external scale, indicative of differential retention; superior recall occurs only when the information is vital to attainment of personal goals. 


\section{Field of Study}

Most research has focused on a single discipline area; there is a paucity of information regarding the relationship between field of study and locus of control. In the two studies located that directly discussed the issue of interdisciplinary differences, the results were different. In the first study, results revealed that internally oriented individuals preferred the liberal arts and the more externally oriented had entered the fields of science and math (Doody, 1980). In the second study, no significant school effects between dentistry, business or education were found (Linder, 1987). Further research in this area needs to be conducted to identify whether more definite correlations occur among fields of study.

\section{Gender Differences}

Research on college attrition has shown that aside from ability, gender is the most powerful factor in determining matriculation (Peterson and Sells, 1973). Despite the fact that gender does not differentiate significantly in either intelligence or academic ability, the educational attainment of women has been traditionally lower. This difference in educational pursuit is also not attributable to significant differences in gender learning styles. Research has shown that while men are more avoidant and women more participatory (Zelazek,1986), these differences do not occur at the $\mathrm{p}<.05$ level.

Safilios-Rothschild (1979) implied that high achieving women lack an internalized belief about their abilities. A woman, by externalizing the reinforcement, tends to take less responsibility for her success and thus reduces its value (Deaux and Emswiller, 1974; 
Frieze et al, 1978). There is some evidence that this external orientation is focused solely in women with a more traditional background, i.e., they saw their reinforcements revolving around family and societal opinions (Brown, 1983).

Research on the locus of control construct has revealed age and ethnic differences (Doody,1980; Linder, 1985), but research concerning investigating the gender variable has had differing results. In two separate studies conducted at the Virginia Commonwealth University, Linder investigated the correlation between gender and locus of control. In a study of undergraduate and graduate students in a teacher education program:

while not reaching statistical significance, the data suggested that males were more internally oriented than females (Linder, 1985, page 7).

In a later study by the same researcher (1987), the results with a population of 631 graduate students in the fields of dentistry, business and education, revealed that males were significantly more internally oriented than females across all three disciplines.

A study of 254 members of the Teacher Corps program showed that women were less internal than their male counterparts. Neel (1978) and Stansbury (1976) found no significant differences between males and females on locus of control with undergraduate subjects. The same results were also in evidence with a graduate population (Cartledge, 1985; Khafaji and Talib, 1981). When the additional variable of race was investigated with locus of control and gender, it was determined that race was almost 20 times more powerful a determinant as gender. Non-Caucausian females were 
perceived to be the most externally oriented, and Caucasian males were the most internally (Doody, 1980).

\section{Summary}

Locus of control is not a construct that remains static throughout a person's lifetime. As a person ages, he or she accumulates experiences that affect his/her perceptions about reinforcements in the environment and it is these perceptual changes that cause fluctuations on the locus of control continuum. As age increases, individuals tend to become increasingly more internal (Neugarten, 1975).

Many locus of control studies have been conducted investigating the relationship between this construct and other dependent variables. Studies have indicated that people with a more internal locus of control have a significant advantage over those who are more external in the acquisition of information, learning and achievement (Seeman, 1963 ; Phares, 1976; Otten, 1977). Thus, locus of control could be an important factor in determining future success in academic endeavors and used when providing vocational counseling or as a entrance requirement factor for graduate school. 


\section{CHAPTER 3 \\ RESEARCH METHOD}

This chapter contains the methodology of this study and includes a description of the research approach and design, the three null hypotheses and their components, the selection of subjects, data collection techniques and data analysis methods. In addition, the methodological assumptions and limitations have been placed in this chapter.

\section{Research Approach}

A survey approach was utilized in this study. No pilot study was conducted since the primary instrument (Reid-Ware Locus of Control) had been used successfully in other studies (Reid and Ware, 1974) and with graduate students (Stack, 1981). The study investigated the relationship between locus of control and the variables of gender and field of study among graduate students. While the sample group already existed (graduate students at The University of Rhode Island), the data on locus of control were not currently available from any sources: therefore, two concurrent surveys were used to collect and link togethor the necessary information.

\section{Research Design}

This was intended as a post-test only design: no treatment was administered to any part of the sample. It was a correlational and cross-sectional multiple group study designed to determine what, if 
any, relationships existed between graduate students' locus of control, their gender and chosen field of study. Investigated was the degree to which variations occured between genders on the locus of control variable and between the six field of study categories on the locus of control. The results of these two correlations were then contrasted to determine which, if any, had a more profound effect on the locus of control variable.

\section{Null Hypotheses}

The following hypotheses, stated in the null form, will be examined during this study:

1. That there is no statistically significant difference in locus-of-control orientation as measured by the total score on the Reid-Ware Locus-of-Control Scale among the field of study categories of graduate students reported on the personal data surveys.

2. That there is no statistically significant difference in locus-of-control orientation as measured by scores on the Reid-Ware Locus-of-Control Scale between genders .

2a. That there is no statistically significant difference on the Self-Control subscale as measured by the self-control score on the Reid-Ware Locus-of-Control Scale between genders reported on the personal data survey. 2b. That there is no statistically significant difference on the Social Systems subscale as measured by the social systems control score on the Reid-Ware Locus-of-Control Scale between genders reported on the personal data survey. 
2c. That there is no statistically significant difference on the Fatalism subscale as measured by the fatalism score on the Reid-Ware Locus-of-Control Scale between genders as reported on the personal data survey.

2d. That there is no statistically significant difference on locus-of-control total scale as measured by the total score on the Reid-Ware Locus-of-Control Scale between genders as reported on the personal data survey.

3. That neither gender and field of study as reported on the personal data survey will be a more dominant variable affecting locus-of-control; both will exert an equal effect.

The level of confidence for significance used for each hypothesis was $\mathrm{p}<.05$.

\section{Selection of Subjects}

This study solicited participation from graduate students at the University of Rhode Island enrolled spring semester 1990, excluding enrolled in the School of Business, Graduate School of Oceanography and in courses offered by the Director of the College of Continuing Education's (CCE) Special Programs Division. The exclusion of particular groups was to keep the population sampled more manageable in size and academic specialization was not a factor in determining exclusion. Participation in this study was on a voluntary basis for the aforementioned graduate students. Only responses from graduate students of American citizenship were to be part of the data analysis in an effort to minimize extraneous variables which could have resulted from acculturation in a foreign setting. 


\section{Instrumentation}

Although the Rotter Scale is the most frequently used measure in internal-external locus of control research, its lack of sensitivity to specific behaviors and attitudes has been documented (Schegel and Crawford,1978). Therefore, this study used the Reid-Ware Locus-of-Control Scale (RWS) to measure locus of control orientation of the respondents. The RWS (Appendix A) is a 45 item belief survey consisting of pairs of alternatives between which the respondent must make a choice. The scale requires approximately 15 minutes to complete and can be self-administered. Scoring of the RWS is accomplished by awarding a point for each external item responded to by the subject. The thirteen buffer pairs are discarded, and the remaining three subscales are scored separately. When a respondent's total is calculated from all three subscales, the sum score ranges from zero (highly internal) to 43 (highly external).

The most important aspect of the RWS is that it differentiates the internal-external orientation of the respondent along three subscales: Self-Control, Social Systems Control and Fatalism. Stack (1981) in a study of female graduate students has shown that statistically significant differences may not occur in internal-external orientation on the Fatalism subscale but be apparent in both Selfcontrol and Social Systems Control subscales.

The test-retest reliability (after 6 weeks) of the RWS is reported as .62 for the Self-Control subscale, .71 for the Social Systems Control subscale, and .63 for the Fatalism subscale. The total score reliability was reported to be .71 . The original population for the reliability studies was undergraduate college students and it has 
been used in research with graduate students (Stack, 1981). Face and content validity was determined by a careful review of the RWS. All 45 paired items concern the subject's perceptions/beliefs about the way he/she deals with his/her social and physical environment. There are 13 buffer items in the RWS but they are difficult to distinguish from the items relating to each subscale.

\section{Data Collection Procedure}

This was a comparative study using a post-test only design; no treatment is being offered to any group. A direct miling was used to distribute the instruments. A cover letter (Appendix A) addressed the orientation of the research, the need for large scale participation and details for completion and return of the instruments. A personal data survey (Appendix B) and the Reid-Ware Locus-of-Control Scale (RWS) (Appendix C) were enclosures to the cover letter. Returns of the survey were accepted for use in the data base for two months after the initial mailing. All surveys received after that date were discarded.

\section{Data Analysis Procedure}

Surveys were returned by a provided, self-addressed stamped envelope. Surveys received in the mail were checked for removal of original mailing labels to preserve anonymity and residual names were removed/ blacked out. Participants who desired a copy of the abridged survey results also enclosed a $3^{\prime \prime}$ x 5 " card with their name and address, and this was also removed from the survey package. Each set of returned surveys was inspected to insure all appropriate 
items had been completed and all pages were intact. The personal data and belief surveys of each respondent were then stapled together.

The respondents to the surveys were categorized according to gender and field of study prior to scoring. The fields of study were grouped as follows to allow for a larger sample size within each set:

Math \& Botany; Chemistry; Computer Science;

Sciences Engineering; Geology; Mathematics;

Laboratory and Clinical Science; Pharmacology;

Physics; Statistics; and Zoology.

Human College Student Personnel; Communicative

Sciences Disorders; Community Planning; Economics;

Education; Gerontology; History; Human

Development, Counseling \& Family Studies;

Library and Information Studies; Marine

Affairs; Physical Education; Political Science;

Psychology; Public Administration; Textiles,

Merchandising and Design.

Fine Arts Fine Arts; Languages; Literature; and

Philosophy.

Business

Accounting; Labor Relations

Health

Nursing; Nutrition; and Physical Therapy

Natural

Agronomy; Animal and Veterinary Science;

Resources Fisheries, Fish Diseases; Natural Resources;

Water Resources; Wildlife Management.

Surveys were coded (based upon information on the personal data survey) according to field of study category, gender, age and 
foreign/ indigenous data. Scoring of the RWS was accomplished using three templates (one for each subscale). Each belief survey was given four scores; self-control, social systems control, fatalism and overall. A summary tally sheet was developed and the total score and all subscale scores were recorded onto it. The information was then entered onto a Macintosh computer using STATVIEW ${ }^{\mathrm{TM}}$, a statistical software package. The entered data were proof read twice to insure they were entered correctly before data analysis occurred. To test Hypothesis 1, a one-way analysis of variance (ANOVA) was used with the $p<.05$ level of confidence for significance between groups. To test Hypothesis 2, a one-way ANOVA was used with the $p<.05$ level of confidence for significance between groups. To test Hypothesis 3, a correlation coefficient was generated for each independent variable.

\section{Methodological Assumptions}

For the purpose of this study, the following assumptions were made:

1. The RWS is a valid instrument to measure locus of control.

2. The respondents will be a representative sample of the population of graduate students at the University of Rhode Island.

3. All respondents cooperated voluntarily and answered the questions honestly and to the best of their ability.

4. The respondents understood the directions, implications of the study and correctly completed the instruments. 


\section{Limitations of the Study}

The following limitations of this study are acknowledged:

1. Since this is a post-test only design, and data are collected only once, it will reflect the respondent's perceptions only at that point in time and may not be a sample of constant behavior.

2. The results of this study are applicable only to the population from which the sample was drawn. Generalizations to other populations are limited to the extent that they are similar. The results are also limited to those graduate students who voluntarily completed the surveys.

3. Due to the self-reporting nature of the belief survey, it is possible that the respondents may choose the more socially acceptable answers rather than respond to items in an inappropriate fashion or they may actually lack adequate awareness of their feelings.

4. The first question on the personal data survey (Appendix A) was unintentionally ambiguous. The aim was to elicit information regarding the site of an individual's acculturation. The original intent was to exclude foreign students from this data analysis because their responses may vary from the U.S. norm. The original wording of this question asked for a response of U.S. citizen, naturalized citizen or foreign (non-U.S.) citizen. Although the data from foreign students were not to be used directly in this study, they were to be available for further research with the graduate student population on the variable of acculturation. Due to concerns that the original wording may have alienated foreign students from responding, 
the wording was changed. As a result of the change, it is unclear how many foreign students actually responded to the survey because the phrase "foreign setting" could mean America to a Chinese citizen or Africa to a French native. Thus all foreign students' responses have been included in this population and may have skewed the results. 5. Ethnicity was not considered as a variable for either American or foreign students. While ethnic background can have a significant effect on an individual's acculturation, in order to limit the size of the study, the affects of ethnicity were not investigated. 
CHAPTER 4

\section{RESULTS}

This chapter includes the results of the statistical analyses of the data collected from both surveys. It contains a description of the subjects, the findings related to the hypotheses, additional findings related to locus-of-control, and a summary.

\section{Description of Subjects}

All graduate students enrolled at the University of Rhode Island spring semester 1990 (except students enrolled in the School of Business, Graduate School of Oceanography and in courses offered by the CCE Special Programs Division) were sent a set of surveys. The surveys were accompanied by a cover letter (Appendix A) stating that participation was completely voluntary and anonymous. A total of 1692 surveys were sent via commercial mail to addresses supplied by the Graduate School, only students with a foreign address (a total of 17) were omitted from the above sample. Participation was encouraged in the cover letter in order to increase the base of information available across disciplines.

\section{Distribution of Sample by Field of Study}

The total number of students who responded to this survey was 998; a total of 804 (730 American students) returned fully completed instruments. A breakdown of the sample by discipline and field of study is presented in Table 1. It is interesting to note, that 
Table 1

Delineation of Surveys by Discipline and Field of Study

\begin{tabular}{|c|c|c|c|c|c|}
\hline $\begin{array}{l}\text { Field } \\
\text { of } \\
\text { Study }\end{array}$ & $\begin{array}{l}\text { Disci- } \\
\text { pline }\end{array}$ & $\begin{array}{l}\text { Complete } \\
\text { Surveys } \\
\text { Received } \\
\end{array}$ & $\begin{array}{l}\text { Percentages } \\
\text { Received }\end{array}$ & $\begin{array}{l}\text { Foreign } \\
\text { Students }\end{array}$ & $\begin{array}{l}\text { Total } \\
\text { Sample }\end{array}$ \\
\hline \multicolumn{6}{|c|}{ Math \& Sciences } \\
\hline & & 217 & $27 \%$ & 44 & 173 \\
\hline & Biology & 12 & & 0 & 12 \\
\hline & Botany & 7 & & 0 & 7 \\
\hline & Chemistry & 10 & & 2 & 8 \\
\hline & Computer Sci. & 10 & & 1 & 21 \\
\hline & Engineering & 85 & & 28 & 57 \\
\hline & Geology & 7 & & 0 & 7 \\
\hline & Lab. Science & 10 & & 1 & 9 \\
\hline & Math & 9 & & 1 & 8 \\
\hline & Pharmacology & 14 & & 4 & 10 \\
\hline & Physics & 6 & & 5 & 1 \\
\hline & Statistics & 2 & & 0 & 2 \\
\hline & Zoology & 2 & & 1 & 1 \\
\hline
\end{tabular}

\section{HUMAN SCIENCES}

$\begin{array}{lrrrr} & \mathbf{3 8 3} & \mathbf{4 8 \%} & \mathbf{1 3} & \mathbf{3 7 0} \\ \text { College Stud. } & 8 & & 0 & 8 \\ \text { Comm. Dis. } & 23 & & 0 & 23 \\ \text { Comm. Plan. } & 11 & 0 & 11 \\ \text { Couns \& Fam } & 2 & & 0 & 2 \\ \text { Economics } & 27 & 7 & 20 \\ \text { Education } & 87 & 2 & 85 \\ \text { Gerontology } & 1 & 0 & 1 \\ \text { History } & 5 & 0 & 5 \\ \text { HCF } & 40 & 2 & 38 \\ \text { Library } & 89 & 1 & 88 \\ \text { Marine Aff. } & 10 & 0 & 10 \\ \text { Physical Ed. } & 19 & 0 & 19 \\ \text { Poli. Sci } & 8 & 0 & 8 \\ \text { Psychology } & 60 & 1 & 59 \\ \text { Public Ad. } & 11 & 0 & 11 \\ \text { Textiles } & 5 & 0 & 5\end{array}$


Table 1 (continued)

Fine Arts

Fine Arts

Languages

Literature

Philosophy

Business

Accounting

Labor Rel.

Health

Nursing

Nutrition

Phys. Ther.
58

1

21

34

2
7\%

5

0

4

1

0

$3 \%$

13

11

24

11

101

74

15

15

$13 \%$

7

2

5

0

0

1
Natural Resources 21

Agronomy 1

Animal Sci.

Fisheries

Fish Diseases 1

Nat. Resources 9
23

13

10

94

72

10

15

$3 \%$

4

17

0

1

2

0

1

$100 \% \quad 74$

730 
although certain fields were to be excluded from the sample in order to reduce the sample size, several were inadvertently included by the Graduate School as part of the mailing.

\section{Distribution of Sample by Gender}

The respondents were categorized by gender as shown in Table 2. The size of the female sample was almost twice as large as the male group-- primarily a result of the inclusion of the female dominated graduate programs in education, library and information sciences and nursing within the human sciences and health fields of study, respectively. Categorization of gender by field of study is provided in Table 3 . In the sample collected by this survey (minus the foreign students), males accounted for $34 \%$ and females for $76 \%$ of the subjects who returned the surveys. Conversely, males dominated the math and sciences field of study at a greater than two to one ratio, and in the natural resource area, males outnumbered the females by almost three to one.

Statistics available for all graduate students enrolled full- and part-time at the University of Rhode Island Fall 1989 are shown in Table 4. The sample population for this study has a greater proportion of females than the total population.

\section{Distribution of Sample by Age}

The subjects were asked to give their ages within the following categories; 20-25, 26-30, 30-35, 35-40, and over 40. (Table 5) Sixty-two percent were 35 or younger and twenty-one percent were 40 or older. Calculated by category, the mean category was 
Table 2

Gender of Subjects

\begin{tabular}{lllll}
\hline \hline Gender & $\begin{array}{l}\text { Subjects } \\
\text { in Group }\end{array}$ & $\begin{array}{l}\text { Foreign } \\
\text { Students }\end{array}$ & $\begin{array}{l}\text { Sample } \\
\text { Used }\end{array}$ & $\begin{array}{l}\text { Percentage } \\
\text { of Sample }\end{array}$ \\
\hline Male & 296 & 51 & 245 & $34 \%$ \\
Female & 508 & 23 & 485 & $76 \%$ \\
\hline
\end{tabular}

Table 3

Gender by Field of Study

\begin{tabular}{lccccccc}
\hline & Math \& & Human & & \multicolumn{2}{c}{ Natural } & Fine \\
Gender & Science & Sciences & Business & Health & Resources & Arts & Total \\
Male & 105 & 89 & 10 & 9 & 20 & 22 & 245 \\
Female & 49 & 297 & 13 & 88 & 7 & 31 & 485 \\
Total & 154 & 386 & 23 & 97 & 27 & 53 & 730
\end{tabular}

Table 4

Gender of Total Population

Gender

Percentage

Male

Female

of Total

Total

1677

1925

3602
$47 \%$

$53 \%$ 
2.962 (equates to 29.81 years) with a standard deviation (SD) of 1.4; the geometric mean was 2.581(equates to 27.91 years), and the medians fell into category 2 (26-30 years).

Statistics available for all graduate students enrolled full- and part-time at the University of Rhode Island Fall 1989 are shown in Table 6. The age distribution within the sample population is roughly equal to that found in the total population.

\section{Distribution of Sample by Degree Program}

The sample collected (including foreign students) was heavily weighted with masters' degree candidates; only one-fifth of the graduate students were currently enrolled in a Ph.D. program (Table 7). Only 5\% of the subjects who returned surveys were enrolled in a non-degree or certificate program. The data revealed that $69 \%$ of all the males who returned surveys were from masters' degree candidates, and $27 \%$ of males were $\mathrm{Ph} . \mathrm{D}$. candidates; $79 \%$ of females were in a masters' degree program and only $16 \%$ were enrolled in a doctoral program (typically Nursing or Psychology) (Table 8).

Table 9 reflects the data on gender within the sample population in relation to composition of degree enrollments. Females accounted for $69 \%$ of the total of masters' degree candidates but only $53 \%$ of the Ph.D. candidates who took part in the research, while men were $31 \%$ of the Masters' candidates and $47 \%$ of the doctoral students who returned complete surveys. 
Table 5

Ages of Subjects

\begin{tabular}{lllll}
\hline Age Group & $\begin{array}{l}\text { Subjects } \\
\text { in Group }\end{array}$ & $\begin{array}{l}\text { Foreign } \\
\text { Students }\end{array}$ & $\begin{array}{l}\text { Total } \\
\text { Sample }\end{array}$ & $\begin{array}{l}\text { Percentage } \\
\text { of Total }\end{array}$ \\
\hline in Years & 148 & 17 & 131 & $18 \%$ \\
$20-25$ & 230 & 33 & 197 & $27 \%$ \\
$31-35$ & 140 & 16 & 124 & $17 \%$ \\
$36-40$ & 129 & 4 & 125 & $17 \%$ \\
OVER 40 & 157 & 4 & 153 & $21 \%$
\end{tabular}

Table 6

Age Distribution of Total Population

\begin{tabular}{lll}
\hline $\begin{array}{l}\text { Age Group } \\
\text { in Years }\end{array}$ & $\begin{array}{l}\text { Total } \\
\text { in Group }\end{array}$ & $\begin{array}{l}\text { Percentage } \\
\text { of Total }\end{array}$ \\
$20-25$ & 567 & $16 \%$ \\
$26-30$ & 1044 & $29 \%$ \\
$31-35$ & 714 & $20 \%$ \\
$36-40$ & 546 & $15 \%$ \\
OVER 40 & 730 & $20 \%$ \\
\end{tabular}


Table 7

Frequency Distribution by Degree

\begin{tabular}{lllll}
\hline \hline $\begin{array}{l}\text { Degree } \\
\text { Program }\end{array}$ & $\begin{array}{l}\text { Total } \\
\text { in Group }\end{array}$ & $\begin{array}{l}\text { Foreign } \\
\text { Students }\end{array}$ & $\begin{array}{l}\text { Sample } \\
\text { in Group }\end{array}$ & $\begin{array}{l}\text { Percentage } \\
\text { of Total }\end{array}$ \\
Masters & 590 & 40 & 550 & $75 \%$ \\
Ph.D. & 177 & 33 & 144 & $20 \%$ - Mode \\
Certificate & 37 & 1 & 36 & $5 \%$ \\
\hline
\end{tabular}

Table 8

Frequency Distribution by Degree and Gender (Indigenous Students Only)

\begin{tabular}{|c|c|c|c|c|c|c|}
\hline $\begin{array}{l}\text { Degree } \\
\text { Program } \\
\end{array}$ & $\begin{array}{l}\text { Males } \\
\text { in Grou }\end{array}$ & $\begin{array}{c}\% \text { of } \\
\text { Males }\end{array}$ & $\begin{array}{l}\text { Females } \\
\text { in Group }\end{array}$ & $\begin{array}{l}\% \text { of } \\
\text { Females }\end{array}$ & $\begin{array}{l}\text { Sample } \\
\text { in Group }\end{array}$ & $\begin{array}{l}\% \text { of } \\
\text { Total } \\
\end{array}$ \\
\hline Masters & 169 & $69 \%$ & 381 & $79 \%$ & 550 & $75 \%$ \\
\hline Ph.D. & 67 & $27 \%$ & 77 & $16 \%$ & 144 & $20 \%$ \\
\hline \multirow[t]{2}{*}{ Certificate } & 9 & $4 \%$ & 27 & $5 \%$ & 36 & $5 \%$ \\
\hline & \multicolumn{4}{|c|}{$\begin{array}{c}\text { Table } 9 \\
\text { Frequency Distribution by Gender and } \\
\text { (Indigenous Students Only) }\end{array}$} & Degree & \\
\hline $\begin{array}{l}\text { Degree } \\
\text { Program }\end{array}$ & $\begin{array}{l}\text { Males } \\
\text { in Group }\end{array}$ & $\begin{array}{l}\% \text { of } \\
\text { Program }\end{array}$ & $\begin{array}{l}\text { Females } \\
\text { in Group }\end{array}$ & $\begin{array}{l}\% \text { of } \\
\text { Program }\end{array}$ & Total & \\
\hline Masters & 169 & $31 \%$ & 381 & $69 \%$ & 550 & \\
\hline Ph.D. & 67 & $47 \%$ & 77 & $53 \%$ & 144 & \\
\hline Certificate & 9 & $25 \%$ & 27 & $75 \%$ & 36 & \\
\hline
\end{tabular}




\section{Discussion of Findings}

The purpose of this study was to examine the differences/ similarities among graduate students at the University of Rhode Island. The comparison was accomplished by grouping the students on the variables of gender and field of study and comparing those variables with the results from a locus of control instrument. In this section the research questions are summarized, the resulting hypotheses stated, and the results of the statistical analyses provided.

\section{Research Question One}

The first question was concerned with comparing the locus of control orientation with the chosen field of graduate education as categorized for the purpose of this study. A one-way analysis of variance was used to test for significance between and among all the groups. The hypothesis was tested at the $\mathrm{p}<.05$ level of significance.

Question 1: Does the chosen field of study of a graduate student have an effect on their locus of control?

Hypothesis 1: There is no statistically significant difference in locus-of-control orientation among field of study categories of graduate students. The means and standard deviations for the field of study groups are presented in Table 10. The mean for each group was calculated as follows; Fine Arts- 12.226, Math and Sciences12.312, Human Sciences- 11.948, Business- 12.652, Natural Resources- 11.882, and Health-10.835. An F-ratio of .97 was computed and was not found significant at the $\mathrm{p}<.05$ level. The null hypothesis was not rejected. 


\section{Research Question Two}

The second question concerned comparing the variable of gender with the scores on the Reid-Ware Locus of Control instrument. Both total score and all three subscale scores were investigated. Four null hypotheses resulted from research question 2. A one-way analysis of variance and Scheffe's post-hoc multiple comparison analysis were used on all four hypotheses. All four hypotheses were tested at the $\mathrm{p}<.05$ level of significance.

Hypothesis 2.a: There is no statistically significant difference on the Self-Control subscale between genders. Means and standard deviations for the two groups are presented in Table 11. The mean for males was 3.335 and the mean for females was 4.016. A F-ratio of 7.447 was calculated which was found to be statistically significant at the $\mathrm{p}<.05$ level. The null hypothesis was rejected.

Hypothesis 2b: There is no statistically significant difference on the Social Systems Control subscale between genders. Table 12 shows the means and standard deviations among and between genders on the Social Systems Control subscale scores. The mean calculated for males was 4.433 and the mean for women was 4.501 . A F-ratio of .112 was calculated and did not show significance at the $\mathrm{p}<.05$ level. Although some difference between the groups is apparent at the $90 \%$ probability level (men are more internal), the null hypothesis was not rejected. 
Table 10

ANOVA Results of Hypothesis 1

\begin{tabular}{llllll}
\hline Group & Count & Mean & Std. Dev. & Std. Error & F \\
\hline & & & & & $*$ \\
FA & 53 & 12.226 & 5.556 & .763 & $* .97$ \\
MS & 154 & 12.312 & 6.143 & .495 & \\
HS & 386 & 11.948 & 5.537 & .282 & \\
BUS & 23 & 12.652 & 6.706 & 1.398 & \\
NR & 17 & 11.882 & 5.337 & 1.294 & \\
HE & 97 & 10.835 & 5.171 & .525 & \\
& & & & &
\end{tabular}

not significant

Table 11

ANOVA Results of Hypothesis 2a

\begin{tabular}{llllll}
\hline Group & Count & Mean & Std. Dev. Std. Error & $\mathrm{F}$ \\
\hline Male & 245 & 3.335 & 2.375 & .152 & $7.447^{*}$ \\
Female & 485 & 4.016 & 3.527 & .16 & \\
\hline${ }^{*} \mathrm{p}<.05$ & & & & &
\end{tabular}

Table 12

ANOVA Results of Hypothesis $2 b$

\begin{tabular}{llllll}
\hline Group & Count & Mean & Std. Dev. & Std. Error & F \\
Male & 245 & 4.433 & 2.529 & .162 & $.112^{*}$ \\
Female & 485 & 4.501 & 2.638 & .12 & \\
\hline
\end{tabular}

* not significant 
Hypothesis 2c: There is no statistically significant difference on the Fatalism subscale between genders. The means and standard deviations among and between genders on the Fatalism subscale are shown in Table 13. The mean for males was 3.637 and the mean for females was 3.779. A F-ratio of .424 was calculated and it was not found to be significant at the $\mathrm{p}<.05$ level. The null hypothesis was not rejected.

Hypothesis 2d: There is no statistically significant difference on locus-of-control total scale between genders. Table 14 shows the means and standard deviations among and between genders on the total score for the locus of control instrument. The mean calculated for males was 11.412 and the mean for females was 12.173. A Fratio of 2.951 was calculated and did not show significance at the $\mathrm{p}<.05$ level. Although some difference between the groups is apparent at the $90 \%$ probability level (men are more internal overall), the null hypothesis was not rejected.

\section{Research Question Three}

The third question concerned whether either variable already examined, gender or field of study, exerted a greater influence on the locus of control construct.

Hypothesis 3: Neither gender nor field of study will be a more dominant variable affecting locus-of-control. A simple correlation corefficient was calculated for the variable gender ewith total score and field of study and total score. The corelation coefficient for gender was $r=.06$ and for field of study was $r=-.07$. Niether 
Table 13

ANOVA Results for Hypothesis 2c

\begin{tabular}{llllll}
\hline Group & Count & Mean & Std. Dev. & Std. Error & $\mathrm{F}$ \\
\hline Male & 245 & 3.637 & 2.766 & .177 & $.424^{*}$ \\
Female & 485 & 3.779 & 2.809 & .128 & \\
\hline
\end{tabular}

* not significant

Table 14

ANOVA Results of Hypothesis 2d

\begin{tabular}{llllll}
\hline Group & Count & Mean & Std. Dev. Std. Error & F \\
Male & 245 & 11.412 & 5.78 & .369 & $2.951^{*}$ \\
Female & 485 & 12.173 & 5.586 & .254 & \\
\hline
\end{tabular}

*not significant 
correlation was significant and each was relatively similar in magnitude thus the hypothesis was not rejected.neither is significant at the $p<.05$ level The null hypothesis is not rejected.

\section{Additional Significant Findings \\ Related to Locus of Control}

Field of Study Comparison on the Social Systems Control Subscale

Since no significant differences were found on the field of study variable when compared with the total score on the locus of control variable, an analysis of variance was conducted for each of the three subscales. Two of the subscales, Fatalism and Self-Control, showed no significant differences between the groups. However, the third subscale, Social Systems Control, showed a difference in the mean scores between the groups (Table 15). The means for the fields of study were calculated to be; Fine Arts- 4.019, Math and Sciences4.929, Human Sciences- 4.425, Business- 5.13, Natural Resources4.882, and Health- 4.000. A F-ratio of 2.337 was computed and ws significant at the $\mathrm{p}<.05$ level.

Table 16 presents the results of the Scheffe post-hoc multiple comparison analysis. The only significant difference found was between the Health group and the Math and Sciences group. It is interesting to note that males and females are quite unequal in their distribution in these two areas of study; males account for $70.5 \%$ of the surveys returned in Math and Sciences but only $9.3 \%$ in the Health field. 


\section{Age and the Locus of Control Construct}

As an individual ages, research has shown that their locus of control becomes increasingly more internal (Neugarten, 1975; Barrow, 1982). Since the data was available on this question, it was decided to investigate whether graduate students at the University of Rhode Island conformed to this model. The results of a five-way analysis of variance are presented in Table 17. The means for the group 20-25 years old was 12.122, the mean for the group 26-30 years old was 12, the mean for the group 31-35 years old was 12.274 , the mean for the group 36 to 40 years old was 12.472 , and the mean for the group over forty years of age was 10.895. A Fration of 1.731 was calculated and this was found not to be significant at the $p<.05$ level. Although there is no general trend of increasing internality with age, a significant difference does occur between the oldest and all other age groups.

Since the total score yielded no statistically significant results, all three subscale scores were subjected to an analysis of variance. Two of the subscale scores, Fatalism and Self-Control, showed no differences between the groups. However, the Social Systems control subscale yielded an F-ratio of 3.912 and was statistically significant at the $\mathrm{p}<.05$ level (Table 18).

Table 19 presents the mean differences between groups and results of the Scheffe post-hoc multiple comparison analyses. Significant differences were shown between the following groups: 20-25 and over $40,26-30$ and over $40,31-35$ and over $40,36-40$ and over 40. The differences between the groups could be 
Table 15

ANOVA Results of Field of Study

on the Social Systems Control Subscale Score

\begin{tabular}{llllll}
\hline \hline Group & Count & Mean & Std. Dev. Std. Error & F \\
FA & 53 & 4.019 & 2.576 & .354 & $2.337^{*}$ \\
MS & 154 & 4.929 & 2.61 & .21 & \\
HS & 386 & 4.425 & 2.604 & .133 & \\
BUS & 23 & 5.13 & 2.849 & .594 & \\
NR & 17 & 4.882 & 2.571 & .624 & \\
HE & 97 & 4 & 2.432 & .247 & \\
& & & & & \\
$* \mathrm{p}<.05$ & & & & &
\end{tabular}

Table 16

Comparison of Fields of Study

on the Social Systems Control Subscale Score

\begin{tabular}{lll}
\hline Comparison & Mean Diff. & Scheffe F-Tes \\
\hline FA vs. MS & -.91 & .974 \\
FA vs. HS & -.406 & .229 \\
FA vs. BUS & -1.112 & .592 \\
FA vs. NR & -.863 & .287 \\
FA vs. HE & .019 & $3.6428 \mathrm{E}-4$ \\
MS vs. HS & .504 & .834 \\
MS vs. BUS & -.202 & .024 \\
MS vs. NR & .046 & $9.764 \mathrm{E}-4$ \\
MS vs. HE & .929 & $1.532 *$ \\
HS vs. BUS & -.706 & .323 \\
HS vs. NR & -.457 & .102 \\
HS vs. HE & .425 & .418 \\
BUS vs. NR & .248 & .018 \\
BUS vs. HE & 1.13 & .709 \\
NR vs. HE & .882 & .336 \\
\hline
\end{tabular}

${ }^{*} \mathrm{p}<.05$ 
Table 17

ANOVA Results of Age Category Compared to the Locus of Control Total Score

\begin{tabular}{llllll}
\hline \hline Group & Count & Mean & Std. Dev. Std. Error & $\mathrm{F}$ \\
$20-25$ & 131 & 12.122 & 5.446 & .476 & $1.731^{*}$ \\
$26-30$ & 197 & 12 & 5.265 & .375 & \\
$31-35$ & 124 & 12.274 & 6.267 & .563 & \\
$36-40$ & 125 & 12.472 & 5.807 & .519 & \\
over 40 & 153 & 10.895 & 5.635 & .456 & \\
\hline
\end{tabular}

* not significant

Table 18

ANOVA Results of Age Category Compared to the Social Systems Control Subscale Score

\begin{tabular}{llllll}
\hline Group & Count & Mean & Std. Dev. & Std. Error & F \\
\hline $20-25$ & 131 & 4.771 & 2.708 & .237 & $3.921^{*}$ \\
$26-30$ & 197 & 4.635 & 2.503 & .178 & \\
$31-35$ & 124 & 4.776 & 2.708 & .243 & \\
$36-40$ & 125 & 4.512 & 2.526 & .226 & \\
over 40 & 153 & 3.765 & 2.499 & .202 & \\
\hline
\end{tabular}


Table 19

Comparison of Age Categories on the Social Systems Control Subscale Score

\begin{tabular}{ccc}
\hline \hline Comparison & Mean Diff. & Scheffe F-Test: \\
\hline 1 vs. 2 & .136 & .055 \\
1 vs. 3 & $4.863 \mathrm{E}-3$ & $5.6612 \mathrm{E}-5$ \\
1 vs. 4 & .259 & .161 \\
1 vs. 5 & 1.006 & $2.685^{*}$ \\
2 vs. 3 & -.132 & .05 \\
2 vs. 4 & .123 & .043 \\
2 vs. 5 & .87 & $2.448^{*}$ \\
3 vs. 4 & .254 & .151 \\
3 vs. 5 & 1.001 & $2.581^{*}$ \\
4 vs. 5 & .747 & $1.444^{*}$ \\
\hline p & &
\end{tabular}


attributable to the fact that the over 40 group was not divided into smaller age groups; much older students were part of this group and if students become increasingly internal the effect could have been to make this group significantly more internal than if it had been $40-45,46-50$, etc.

Foreign versus Indigenous Students on Locus of Control Variable

Previous research on the locus of control variable among graduate students has either ignored the variable of foreign acculturation (Barrow, 1982; Stack, 1981) or deleted the data collected from foreign students entirely (Doody, 1980). Since social learning theory emphasizes the importance of the environment in which the reinforcement is received, it is an intriguing question of whether differences in environment have an effect on the locus of control construct. The means and standard deviation of foreign and indigenous graduate students are on the total score of the locus of control instrument presented in Table 20. The mean for foreign students is 13.903 and the mean for indigenous students is 11.923 . An F-ratio of 8.453 was calculated and is significant at the $\mathrm{p}<.05$ level. Thus indigenous students are significantly more internal than foreign students.

Since a significant difference was shown between foreign and indigenous students on the total score, the scores for the three subscales were subjected to an analysis if variance. Tables 21-23 show the means and standard deviations for the subscales of Social Systems Control, Fatalism and Self Control respectively. The mean for foreign students on the Social Systems Control subscore is 5.419 
Table 20

ANOVA Results of Foreign vs. Indigenous Students on Locus of Control Total Score

\begin{tabular}{llllll}
\hline \hline Group & Count & Mean & Std. Dev. & Std. Error & $\mathrm{F}$ \\
Foreign & 73 & 13.903 & 4.798 & .558 & $8.453^{*}$ \\
Indigenous & 730 & 11.923 & 5.661 & .21 & \\
\hline${ }^{*} \mathrm{p}<.05$ & & & & &
\end{tabular}

Table 21

ANOVA Results of Foreign vs. Indigenous Students on Social Systems Control Subscale Score

\begin{tabular}{|c|c|c|c|c|c|}
\hline Group & Count & Mean & Std. Dev. & Std. Error & $\mathrm{F}$ \\
\hline Foreign & 73 & 5.419 & 2.477 & .288 & $6.024 *$ \\
\hline Indigenous & 730 & 4.476 & 2.601 & .096 & \\
\hline
\end{tabular}


Table 22

ANOVA Results of Foreign vs. Indigenous Students on Fatalism Score

\begin{tabular}{llllll}
\hline Group & Count & Mean & Std. Dev. & Std. Error & $F$ \\
\hline Foreign & 73 & 4.658 & 2.633 & .306 & $6.024^{*}$ \\
Indigenous & 730 & 3.735 & 2.794 & .103 & \\
\hline${ }^{*} \mathrm{p}<.05$ & & & & &
\end{tabular}

Table 23

ANOVA Results of Foreign vs. Indigenous Students on Self Control Subscale Score

\begin{tabular}{llllll}
\hline Group & Count & Mean & Std. Dev. & Std. Error & F \\
Foreign & 73 & 3.919 & 1.936 & .225 & .113 \\
Indigenous & 730 & 3.791 & 3.202 & .119 & \\
* not significant & & & & &
\end{tabular}


and the mean for indigenous students is 4.476. A F-ratio of 8.93 was calculated and is significant at the p<.05 level. Therefore, foreign students feel they have significantly less control over Social Systems in their environments.

Table 22 shows the means and standard deviations on the Fatalism subscale. The mean for foreign students is 4.658 and the mean for indigenous students is 3.735. The F-ratio was calculated to be 6.024 and is significant at the $p<.05$ level. Thus, foreign students believe that luck, fate or providence plays a more powerful role in their life than indigenous students.

The means and standard deviations of the third subscale, SelfControl, are shown in Table 23. The mean for foreign students is 3.919 and the mean for indigenous students is 3.791. A F-ratio of .113 was calculated and failed to be significant at the $p<.05$ level; indicating that foreign and indigenous students do not vary in their belief in the ability to control their own actions.

\section{Sample Population Related to Normative Sample}

The results of a comparison of the scores of this sample to the subjects in an earlier study that used this instrument (Stack, 1981) and the normative sample (Reid and Ware, 1974) for the total score and all three subscales are shown in Table 24. It was found that this study's sample was significantly more internal than the normative sample (composed of undergraduate psychology students) but that it was less internal than the Stack sample composed of 164 female graduate students from 5 San Diego County universities and colleges. 
Table 24

Sample Population Compared to

Normative Sample and Stack Sample (1981)

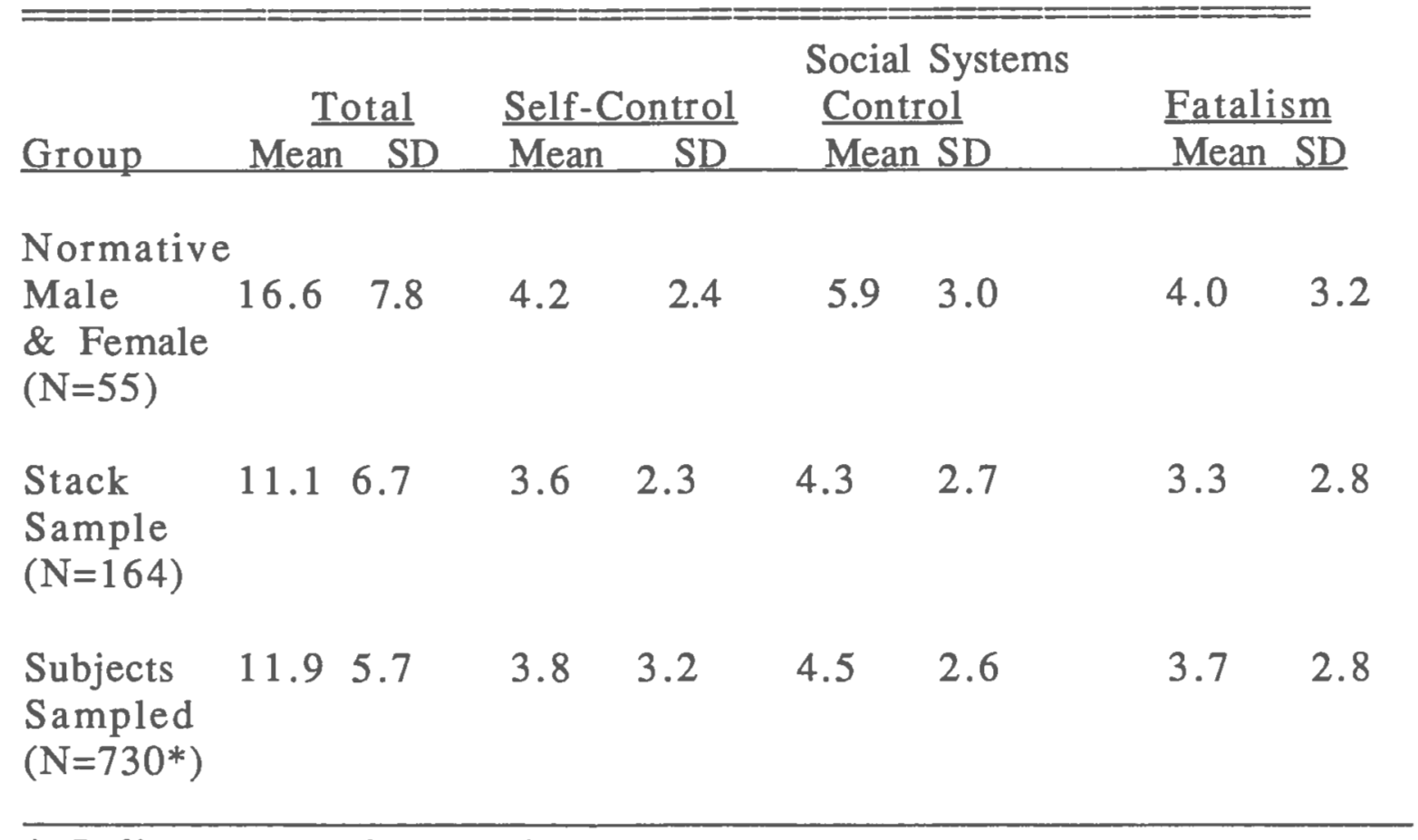

* Indigenous students only 


\section{CHAPTER 5}

\section{SUMMARY, CONCLUSIONS AND RECOMMENDATIONS}

\section{Summary}

Although many studies have been conducted investigating the relationship betwen gender and locus of control, the results of these studies have differed. Insufficient studies have been conducted to determine if significant differences exist between individuals enrolled in various academic disciplines on the locus of control construct. Therefore, the purpose of this study was twofold: (1) to investigate the relationship between gender and locus of control and (2) to determine if field of study has an impact on the locus of control construct.

The principal findings of this study were:

(1) No significant differences were shown to exist (at the $p<.05$ level) between genders on the total scale. On the Self-Control subscale, significant differences were shown between the genders.; on the Fatalism subscale, no significant difference was shown between the genders; on the Social Systems Control subscale, no significant differences were shown to exist at the $p<.05$ level.

(2) Significant differences were not found on the locus of control construct between academic disciplines as delineated into the six field of study categories by this study.

Additional findings indicate that:

(1) Although no differences were found between academic disciplines on the locus of control total score; significant differences were found between the individuals enrolled in the Math and 
Sciences and those enrolled in Health fields on the Social Systems Control subscale. No differences were found between any field of study categories on the Fatalism or Self-Control subscales.

(2) Differences were shown between the age categories on the locus of control construct. The older students (over 40) scored significantly lower on the Social Systems Control subscale than younger students (all four other groups).

(3) Significant differences were found between foreign and indigenous students on the total score of the locus of control instrument and two of its three component subscales (Fatalism and Social Systems Control).

\section{Discussion}

Locus of control is a personality characteristic that identifies individuals on one end of the continuum (internal) as being more likely to succeed in information acquisition (Seeman, 1963), cognitive processing (Glover and Sautter, 1976) and therefore in the larger task of academic endeavors (Otten,1977). Internals describe themselves as more active, striving, achieving, powerful, and effective (Hersch and Scheibe, 1967). In addition, research clearly identifies internals as superior in their efforts at coping with and gaining a measure of control over their environments (Phares, 1976).

Although no significant differences between locus of control total scores and field of study were found in this study, this could be due to the chosen means of categorizing disciplines as Math and Sciences, Human Sciences, Fine Arts, Business, Natural Resources and Health. Additionally, the small sample size from the categories of 
Fine Arts, Natural Resources and Business, could have sufficiently skewed the mean, making the analysis of variance between and among those categories dubious.

The difference between the field of study groups on the Social Systems Control subscale seems attributable to the proportional difference in gender between the Math and Science field (heavily male) and the Health field (predominantly female): In light of the analysis of variance results on this subscale as related to the gender variable (significant at $90 \%$ probability), it is likely that field of study was not the factor influencing the locus of control variability on this subscale.

The Reid-Ware Locus-of-Control Survey (RWS) instrument was chosen for this study because it divided the locus of control construct into three component subscales. Previous research had shown conflicting results on the gender versus locus of control issue and the RWS was chosen to determine if the difference between genders lay in one of the subscales and not in the total score (possibly accounting for the diverging results in various studies). Significant differences were not shown between genders on the total score. However, males were significantly more internal than females on the Self-Control subscale and different, but again not significantly, on the Social Systems Control subscale.

The results of this study-- that men are more internal on the Self-Control subscale, but not on the Fatalism, Social Systems Control or total scores; seems rooted in gender specific acculturation. Men and women appear to be acculturated in the same fashion on the notion of fate, luck or providence; their beliefs a result of societal and 
personal experience, (differing in individual circumstances that are not gender specific). However, from the results of this study it seems apparent that American mores and traditions have given women the perception that they are less powerful in controlling political and social institutions and less able to control their own emotions and personal responses to environmental factors. It is also of note that while women are scoring lower in these areas, they are maintaining a percentage of enrollment in both Masters' and Ph.D. programs (Tables 7 and 8), well above that of males. Therefore, while females see themselves as less able to control themselves and their environment, this lack of control is not perceived as a sufficient obstacle to impede the academic process and pursuit of a graduate degree.

The analysis of variance conducted on this sample and the variables of age and locus of control, yield results similar to other studies that investigated the age variable (Stack, 1981; Barrow, 1982). The greatest differences between the groups were between the oldest group (over 40 years of age) contrasted with all other groups. The over 40 group were significantly more internal than any other age group. Since success in academic endeavors has been shown to be positively correlated with internal locus of control (Seeman, 1963 ; Otten, 1977) those persons who do not pursue a graduate degree because they may feel they are to old to reenter the academic environment may do better than they believe.

Acculturation is an important component of social learning theory; individuals learn what behaviors will be reinforced (expectancy) within their environment and what attitudes are 
socially acceptable. While cultures vary between and across national borders, it was easiesr to segregate possible differences between groups based upon indigenous/ foreign status than attempting to solicit data on cultural ties within a national area. This bimodality (foreign/indigenous) yielded the most significant differences of any of the variables examined (age, field of study, gender). The two groups varied on the total score, and on the two subscales, Fatalism and Social Systems Control. No differences were apparent between the groups on the Self-Control subscale. Foreign graduate students in this sample were significantly more external than indigenous students--obviously a result of their acculturation in a different setting.

\section{Conclusions}

As a result of this study, the following conclusions were drawn:

1. There is no difference in locus of control orientation between any of the fields of study included in this study. Differences may occur between individuals or among and between other variables, but when the individual scores within each field of study are summed and a mean for each group calculated, the groups are almost homogenous. The significant difference found between the Math and Science category and the Health category could be attributable to the compositions of those groups; Math and Science is predominantly male and Health is predominantly female.

2. There is a tendency for female graduate students to be more external than male graduate students, particularly in the areas of 
self-control, where they are significantly different, and in the area of social system control. There is no difference between the genders in fatalism.

3. Foreign graduate students are significantly more external than indigenous students. There are significant differences in the areas of fatalism and social systems control; foreign students feel they have less control over their political and social institutions and also believe more strongly in the effects of fate. No differences exist in this sample between the foreign and indigenous students on the issue of self-control.

4. In general, the older students perceive greater personal control over environment, self-achievement and fate.

\section{Implications}

Graduate school is a challenging and demanding environment which requires scholastic ambition, goal setting and achievement, and the ability to surmount obstacles in the environment. In order to matriculate, graduate students must have provided their own motivation and direction to complete all the stipulated tasks as required by their academic institution. Acquisition of a graduate degree is a significant accomplishment that occurs only after intensive preparation and execution. It is reasonable to assume that since considerable research shows that high achievement is related to internal locus of control (Hazen, 1980; Otten, 1977; Phares, 1976), determining locus of control could also help to differentiate the probability of success in graduate school. 
As previously stated, locus of control scores are not static for an individual; internal-external scores can be altered by a range of conditions, varying from very specific influences that are transitory and changes that have a more permanent effect (Phares, 1976). Change is made possible by providing the proper selection of new experiences; to help someone become increasingly internal, he/she should be led to see how his/her actions directly lead to positive or negative reinforcements in their environment. Once these individuals perceive the importance of their actions in attaining their goals, and minimize the influence of luck, their ability to further succeed in academic endeavors will have been enhanced. Additionally, improved internal locus of control will enhance coping efforts and achievement behaviors (Phares, 1976). Therefore, instructors and counselors should do everything possible to enhance the situations that would develop a more internal focus in their graduate students, especially female students since they are more external than males.

While not originally intending to gather data on age versus locus of control, it is interesting to note the results of this study are consistent with previous research on this variable; older students are more internal than their younger counterparts. Unfortunately, since success in academic endeavors is correlated with internal locus of control, it would seem that it could be more efficient to recruit older students.

\section{Areas for Further Research}

It was suggested in the late 1970's (Phares, 1976, page 174) 
and still holds true today that further research on the locus of control variable should include development of a more sophisticated locus of control instrument. The current instruments (both Rotter and ReidWare) are gender specific-- possibly alienating the female subjects (changing the validity of the instrument) and overly redundant. Ten percent of the respondents in this sample cited gender specificity as a complaint and many did not finish the survey for this reason. Many of the questions are dated (there is no longer a perceived housing shortage). Additionally, a new instrument would have more current data on a normative sample that would be more "in line" with the generation of students enrolled in the 1990's and beyond.

A study on differences in gender on the locus of control variable is important only if a new locus of control instrument is formulated. The gender specificity inherent in the current instruments may have sufficiently skewed the results of this and earlier studies, therefore the question of whether males are really more internal than females has not been appropriately addressed.

A pilot study is an absolute requirement for any research in this area using the current instruments. It is necessary to insure that the population is receptive to these surveys and to identify any problem/ questionable areas in ancillary surveys. Data on age, field of study and foreign status should be carefully gathered to insure they meet the final needs of the investigator. Classification of data into categories is useful for analysis, but the data can be gathered in a non-classified manner and then categorized by the researcher prior to analysis. 
Research into the area of foreign versus indigenous graduate student locus of control seems particularly promising. However, a longitudinal study that investigated the relationship between locus of control and degree attainment in foreign students is necessary before it is assumed that internal locus of control is also a predictor of academic achievement for everyone. The variable of specific culture should also be addressed in a foreign versus indigenous study. Just as other cultures vary from our own, they may vary among themselves. With the growing number of foreign graduate students enrolled in universities and colleges within the United States, the importance of these studies can not be overemphasized. 


\section{REFERENCES CITED}

Allen, A. R. (1977). Student locus of control and teaching style in relation to college reading improvement. Reading Improvement. 14: 104-5.

Association for the Study of Higher Education.(1987, November). A decade of research on graduate students: A review of the literature in academic journals. Paper presented at the Annual Meeting, Baltimore, MD. (ERIC Document Reproduction Service No. ED 292 383).

Barrow, Bernice Rosemary. 1982. Graduate student development of purpose: Career maturity, educational maturity. and locus of control. Dissertations Abstracts International, 43, 1845A (University Microfilms No. 8226725).

Berg, H. M. and Ferber, M. A. (1983). Men and women graduate students: Who suceeds and why? Journal of Higher Education 54 (6): $629-648$.

Brown, Ric (1983). Locus of control and sex role orientation of women graduate students. College Student Journal. 17, (1): 10-12.

Cartledge, Carolyn M. (1985, April). Locus of control: A comparison of developmental studies, undergraduate, and graduate students. Paper presented at the Annual Developmental Studies Conference, Jekyll Island, GA. (ERIC Document Reproduction Service No. ED257516).

Deux, K. and Emswiller, T. (1974) Explanations of successful performance on sex-linked tasks: What is skill for the male is luck for the female. Journal of Personality and Social Psychology, 29 :

Doody, Leonore Marie Cecily Gutierrez. (1980). Perceived locus of control, dogmatism, and academic discipline preference of female and male graduate students of varied race. (Doctoral dissertation, University of Houston, 1980). Dissertations Abstracts International, 41. 1970B 
Glover, John A. and Sautter, Fred. (1976). An investigation of the relationship of four components of creativity to locus of control. Social Behavior and Personality, 4 (2): 257-60.

Guiterriez, Raymond, Joseph. (1982). A study of the relation between locus of control and risk taking for graduate students in education. (Unpublished Master's Thesis, California State University, Northridge)

Hazen, Margaret Maria. (1980). The effect of locus of control and two college environments on achievement and attitudes. Dissertations Abstracts International, 40, 3809A (University Microfilms No. 8002295).

Khajafi, S. and Talib, S. (1981). The relationship between internalexternal locus of control, educational level, age and gender. Dissertations Abstracts International, 42, 4239-B (University Microfilms No. 8206160)

Lefcourt, Herbert M. (1976). Locus of control: Current trends in theory and research. New York: John Wiley \& Sons.

Levenson, H. (1972). Distinctions within the concept of internalexternal locus of control: Development of a new scale. Proceedings, 80th Annual Convention. APA. 7: 262-262.

Linder, Frederic. (1985, April). Locus of control and value orientations of undergraduate and graduate students in a teacher education program. Paper presented at the Annual Meeting of the American Educational Research Association, Chicago, IL. (ERIC Document Reproduction Service No. ED 259030).

Linder, Frederic. (1987, February). Locus of control and values of adult learners in schools of business, dentistry, and education. Paper presented at the Annual Meeting of the Eastern Educational Research Association, Boston, MA.(ERIC Document Reproduction Service No. ED283479).

Lozoff, Marjorie M. (1976). Interpersonal relations and autonomy. In Joseph Katz, \& Rodney T. Hartnett (Eds.), Scholars in the making. Cambridge, Ma: Ballinger Publishing Company, pp 141-160. 
MacDonald, A. P. (1970). Internal-external locus of control and the practice of birth control. Psychological Reports, XXVII, (August):206.

Madden, Margaret E. and Carli, Linda. (1981). Students' satisfaction with graduate school and attributions of control and responsibility.

Paper presented at the 52nd Annual Meeting of the Eastern Psychological Association, New York, New York (ERIC Document Reproduction Service No. ED211866)

Mirels, H. L. (1970). Dimensions of internal versus external control. Journal of Consulting and Clinical Psychology, 33: 654-660.

Neel, L. S. (1979). The relationships among career maturity, locus of control, socioeconomic status, race and sex of a sample of college freshmen at three universities. Dissertations Abstracts International, 39. 4012A (University Microfilms No. 7903716).

Neugarten, Bernice (1975). Middle Age and Aging: A Reader in Social Psychology. Chicago:University of Chicago Press.

Norwicki, S. and Walker, C. (1973). The role of generalized and specific expectancies in determining academic achievement. Atlanta: Emory University. (ERIC Document Reporduction Service No. ED085075).

Otten M. W. (1977). Inventory and expressive measures of locus of control and Academic performance: A five-year outcome study. Journal of Personality Assessment, XL, 6, 644-49.

Patterson, M. and Sells, L. (1973). Women Dropouts from Higher Education. American Women on the Move eds. Alice S. Rossi and Ann Calderwood. New York: Russell Sage Foundation.

Phares, E. Jerry. (December,1968). Differential utilization of information as a function of internal-external control. Journal of Personality, XXXVI, 649-62.

Plant, Walter T. and Telford, Charles W. (August, 1966). Changes in personality for groups completing different amounts of college over two years. Genetic Psychology Monographs, 74, 3-36.

Reid, David W. and Ware, Edward E. (April,1974). Multidimensionality of internal versus external control: Addition of a 
third dimension and non-distinction of self versus others. Canadian Journal of Behavioural Science, 6, 2, 131-142.

Roemer, R. E. (1983) Changing patterns of degree selection among women: 1970-78. Research in Higher Education 18 (2) : 435-454.

Rotter, J.B. and R.C. Mulry. (1965). Internal versus external control of reinforcements and decision time. Journal of Personality and Social Psychology, II, (4), 598-604.

Safilios- Rothschild, C. (1979). Sex role socialization and sex discrimination: A synthesis and critique of the literature.

Washington, D. C.: National Institute of Education,

Schegel, Ronald P., and Craig A. Crawford. (1978). Multidimensional locus of Control and drug use among high school students. Canadian Journal of Behavioural Science, X, 2, 149.

Seeman, Melvin (November, 1963). Alienation and social learning in a reformatory. The American Journal of Sociology. LXIX : 270-84.

Stack, Shirley Leon. (1981). The relationship between locus of control and perceived obstacles in graduate school for female students. Dissertations Abstracts International., 42, 752B (University Microfilms No. 8116174)

Stansbury, J. C. (1977). Maturity of vocational attitudes and locus of control as dimensions of vocational personality types. Dissertations Abstracts International. 37, 4147A (University Microfilms No. 7630026)

Turcotte, R. B. (1983) Enrollment management at the graduate level. The Journal of College Admissions, 27: 24 - 28

Zelazek, John R. (1986). Learning styles, gender, and life cycle stage: Relationships with respect to graduate students. (ERIC Document Reproduction Service No. ED276371) 


\section{APPENDICES}

61 


\section{APPENDIX A}

\section{Cover Letter}

Date

Dear Fellow Graduate Student:

As part of the requirements for my Master of Arts degree, I am conducting a study of graduate students examining the relationship between field of study, gender and personal beliefs. Previous research has shown that personal beliefs greatly influence development of purpose and length of study within graduate school and that differences are greater between fields of study than between genders.

I am striving to bring the results of this study together quickly, and I encourage you to promptly complete these two short questionnaires so that your responses can be included in my data base. Your participation in this study is valuable in increasing the representative sample of graduate students across fields of study.

Enclosed is a self-addressed, stamped envelope for your convenience in returning the materials. Your responses will be anonymous and will be used for research purposes only.

If you would like a copy of the summary of results when the study is completed, please enclose your name and address on a $3 " \mathrm{x}$ 5" card.

Thank you very much in advance for your participation.

\section{Mary Fetherston}

Graduate Student in Adult Education

University of Rhode Island 


\section{APPENDIX B \\ PERSONAL DATA SURVEY}

\section{PERSONAL DATA:}

Please complete the following as completely as possible by circling the appropriate response or supplying another answer if you do not fit in the supplied categories. This data will be used for research purposes only.

1. Before my eighteenth birthday, I spent years in a foreign setting:

0 2-5 years 5-8 years 8-10 years more than 10 years

2. I am male female

3. I am years old.

$$
\text { 20-25 26-30 } 30-35 \quad 35-40 \quad \text { over } 40
$$

4. I am currently fulfilling requirements for:

MA/MS

$\mathrm{PhD}$

Certificate of study

Post-doctoral study

5. My current field of study is:

\begin{tabular}{|c|c|}
\hline Anthropology & Biology \\
\hline Botany & Chemistry/Biochemistry \\
\hline Communications & Communications Disorders \\
\hline Computer Science & Economics \\
\hline Education & Engineering \\
\hline Fine Arts & Geology \\
\hline Gerontology & History \\
\hline HCF & Language \\
\hline Literature & Mathematics \\
\hline Music & Nursing \\
\hline Pharmacology & Philosophy \\
\hline Physical Education & Physics \\
\hline Political Science & Psychology \\
\hline Sociology & Textiles, Merchandising \& \\
\hline Zoology & Design \\
\hline
\end{tabular}




\section{APPENDIX C}

\section{REID-WARE LOCUS-OF-CONTROL SCALE \\ (Belief Survey)}

\section{Belief Survey}

This questionnaire is a measure of personal belief; obviously there are no right or wrong answers. Each item consists of a pair of alternatives lettered (A) or (B). Please select the one statement of each pair (and only one) which you more strongly believe as far as you are concerned. Be sure to select the one you actually believe to be more true rather than the one you think you should choose or the one you would like to be true.

Please answer the items carefully, but do not spend too much time on any one item. Be sure to find an answer for every choice. Circle the letter of the statement (A) (B) which you choose.

In some cases you may discover that you believe both statements or neither one. In such cases, be sure to select the one you more strongly believe to be the case as far as you are concerned. Also try to respond to each item independently when making your choice; do not be influenced by your previous choices.

1. (A) Various sports activities in the community help increase solidarity amongst people in the community.

(B) Various sports activities in the community can lead to rivalry detrimental to the solidarity of the community.

2. (A) War brings out the worst aspects of men.

(B) Although war is terrible, it can have some value.

3. (A)There will always be war no matter how hard people try to prevent them.

(B) One of the major reasons why we have war is because people do not take enough interest in politics.

4. (A) Even when there was nothing forcing me, I have found that I will sometimes do things I really did not want to do.

(B) I always feel in control of what I am doing. 
5. (A) There are institutions in our society that have considerable control over me.

(B) Little in this world controls me; I can usually do what I decide to do.

6. (A) I would like to live in a small town or a rural environment. (B) I would like to live in a large city.

7. (A) For the average citizen, becoming a success is a matter of hard work; luck

has little or nothing to do with it.

(B) For the average guy, getting a good job depends mainly on being in the right place at the right time.

8. (A) Patriotism demands that the citizens of a nation participate in any war.

(B) To be a patriot for one's country does not necessarily mean he must go to war for his country.

9. (A) In my case, getting what I want has little or nothing to do with luck.

(B) It is not always wise for me to plan too far ahead because many things turn out to be a matter of good or bad fortune anyhow.

10. (A) Sometimes I impulsively do things which at other times I definitely would not let myself do.

(B) I find that I can keep my impulses in control.

11. (A) In many situations what happens to people seems to be determined by fate.

(B) People do not realize how much they personally determine their own outcomes.

12. (A) College students should be trained in times of peace to assume military duties.

(B) The evils of war are greater than the possible benefits.

13. (A) Most people do not realize the extent to which their lives are controlled by accidental happenings.

(B) For any person, there is no such thing as luck.

14. (A) If I put my mind to it, I could have an important influence 
on what a politician does in office.

(B) When I look at it carefully, I realize it is impossible for me to have any really important influence over what politicians do.

15. (A) With fate the way it is, many times I feel I have little influence over the things that happen to me.

(B) It is impossible for me to believe that chance or luck plays an important role in my life.

16. (A) When I put my mind to it, I can restrain my emotions.

(B) There are moments when I cannot subdue my emotions and keep them in check.

17. (A) Every person should give some of his time for the good of his town or country.

(B) People would be a lot better off if they could live far away from other people and never have to do anything for them.

18. (A) As far as the affairs of our country are concerned, most people are the victims of forces they do not control and frequently do not understand.

(B) By taking part in political and social events, the people can directly control much of the country's affairs.

19. (A) People cannot always hold back their personal desires; they will behave out of impulse.

(B) If they want to, people can always directly control their immediate wishes and not let these motives determine their total behavior.

20. (A) Many times I feel I might just as well decide what to do by flipping a coin.

(B) In most cases I do not depend on luck when I decide to do something.

21. (A) Our Federal Government should promote the mass production of low rental apartment buildings to reduce the housing shortage,

(B) The best way for our government to reduce the housing shortage is to make low interest mortgages available for the building of low cost single-family dwellings. 
22. (A) I do not know why politicians make the decisions they do. (B) It is easy for me to understand why politicians do the things they do.

23. (A) Although sometimes it is difficult, I can always restrain my immediate behavior.

(B) Something I cannot completely master is my behavioral tendencies.

24. (A) In the long run, people receive the respect and good outcomes they worked for.

(B) Unfortunately, because of misfortune or bad luck, the average person's worth often passes unrecognized no matter how hard he tries.

25. (A) With enough effort, people can wipe out political corruption. (B) It is difficult for people to have much control over the things politicians do in office.

26. (A) Letting your friends down is not so bad because you cannot do good all the time for everybody.

(B) I feel very bad when I have failed to finish a job I have promised to do.

27. (A) By active participation in the appropriate political organizations, people can do a lot to keep the cost of living from going higher.

(B) There is very little people can do to keep the cost of living from going higher.

28. (A) It is possible for me to behave in a manner very different from the way I would want to behave.

(B) It would be very difficult for me not to have mastery over the way I behave.

29. (A) In this world I am affected by social forces which I neither control nor understand.

(B) It is easy for me to avoid and function independently from any social forces that may attempt to have control over me.

30. (A) It hurts more to lose money than to lose a friend.

(B) The people are the most important thing in this world of ours. 
31. (A) What people get out of life is always a function of how much effort they put into it.

(B) Quite often one finds that what happens to people has no relation to what they do; what happens just happens.

32. (A) Generally speaking, my behavior is not governed by others. (B) My behavior is frequently determined by other influential people.

33. (A) People can and should do what they want to do now and in the future.

(B) There is no point in people's planning their lives too far in advance because other groups of people in our society will invariably upset their plans.

34. (A) Happiness is having your own car and house.

(B) Happiness to most people is having their own close friends.

35. (A) There is no such thing as luck; what happens to me is a result of my own behavior.

(B) Sometimes I cannot understand how I can have such poor luck.

36. (A) More emphasis should be placed on teaching the principles of religion in public school.

(B) Religion should not be included in a school curriculum; it can be taught in church.

37. (A) Many of the unhappy things in people's lives are at least partly due to bad luck.

(B) People's misfortunes result from the mistakes they make.

38. (A) Self-regulation of one's behavior is always possible.

(B) I frequently find that when certain things happen to me, I cannot restrain my reaction.

39. (A) The average man can have an influence in government decisions.

(B) This world is run by a few people in power, and there is not much the little person can do about it, 
40. (A) When I make my mind up, I can always resist the temptation and keep control of my behavior.

(B) Even if I try not to submit, I often find I cannot control myself from some of the enticements in life such as overeating or drinking.

41. (A) My getting a good job or promotion in the future will depend a lot on my getting the right turn of fate.

(B) When I get a good job, it is always a direct result of my own ability and/or motivation.

42. (A) Successful people are mostly honest and good.

(B) One should not always associate achievement with integrity and honor.

43. (A) Most people do not understand why politicians behave the way they do.

(B) In the long run, people are responsible for bad government on a national as well as on a local level.

44. (A) I often realize that despite my best efforts, some outcomes seem to happen as if fate planned it that way.

(B) The misfortunes and successes I have had were the direct result of my own behavior.

45. (A) Most people are good and kind.

(B) People will not help others unless circumstances force them to.

PLEASE be sure you followed the instructions and circled ONLY ONE LETTER for EVERY item.

THANK YOU VERY MUCH FOR COMPLETING THIS SURVEY!

(Reid and Ware, 1974) 


\section{BIBLIOGRAPHY}

Allen, A. R. (1977). Student locus of control and teaching style in relation to college reading improvement. Reading Improvement. 14: 104-5.

Association for the Study of Higher Education.(1987, November). A decade of research on graduate students: A review of the literature in academic journals. Paper presented at the Annual Meeting, Baltimore, MD. (ERIC Document Reproduction Service No. ED 292 383).

Barrow, Bernice Rosemary. 1982. Graduate student development of purpose: Career maturity, educational maturity. and locus of control. Dissertations Abstracts International, 43. 1845A (University Microfilms No. 8226725).

Berg, H. M. and Ferber, M. A. (1983). Men and women graduate students: Who suceeds and why? Journal of Higher Education 54 (6): $629-648$.

Brown, Ric (1983). Locus of control and sex role orientation of women graduate students. College Student Journal. 17, (1): 10-12.

Cartledge, Carolyn M. (1985, April). Locus of control: A comparison of developmental studies. undergraduate, and graduate students. Paper presented at the Annual Developmental Studies Conference, Jekyll Island, GA. (ERIC Document Reproduction Service No. ED257516).

Deux, K. and Emswiller, T. (1974) Explanations of successful performance on sex-linked tasks: What is skill for the male is luck for the female. Journal of Personality and Social Psychology, 29 :

Doody, Leonore Marie Cecily Gutierrez. (1980). Perceived locus of control, dogmatism, and academic discipline preference of female and male graduate students of varied race. (Doctoral dissertation, University of Houston, 1980). Dissertations Abstracts International. 41. 1970B 
Glover, John A. and Sautter, Fred. (1976). An investigation of the relationship of four components of creativity to locus of control. Social Behavior and Personality, 4 (2): 257-60.

Guiterriez, Raymond, Joseph. (1982). A study of the relation between locus of control and risk taking for graduate students in education. (Unpublished Master's Thesis, California State University, Northridge)

Hazen, Margaret Maria. (1980). The effect of locus of control and two college environments on achievement and attitudes. Dissertations Abstracts International, 40, 3809A (University Microfilms No. 8002295).

Khajafi, S. and Talib, S. (1981). The relationship between internalexternal locus of control, educational level, age and gender. Dissertations Abstracts International, 42. 4239-B (University Microfilms No. 8206160)

Lefcourt, Herbert M. (1976). Locus of control: Current trends in theory and research. New York: John Wiley \& Sons.

Levenson, H. (1972). Distinctions within the concept of internalexternal locus of control: Development of a new scale. Proceedings. 80th Annual Convention. APA. 7: 262-262.

Linder, Frederic. (1985, April). Locus of control and value orientations of undergraduate and graduate students in a teacher education program. Paper presented at the Annual Meeting of the American Educational Research Association, Chicago, IL. (ERIC Document Reproduction Service No. ED 259030).

Linder, Frederic. (1987, February). Locus of control and values of adult learners in schools of business. dentistry, and education. Paper presented at the Annual Meeting of the Eastern Educational Research Association, Boston, MA.(ERIC Document Reproduction Service No. ED283479).

Lozoff, Marjorie M. (1976). Interpersonal relations and autonomy. In Joseph Katz, \& Rodney T. Hartnett (Eds.) , Scholars in the making. Cambridge, Ma: Ballinger Publishing Company, pp 141-160. 
MacDonald, A. P. (1970). Internal-external locus of control and the practice of birth control. Psycholegical Reports. XXVII, (August):206.

Madden, Margaret E. and Carli, Linda. (1981). Students' satisfaction with graduate school and attributions of control and responsibility. Paper presented at the 52nd Annual Meeting of the Eastern Psychological Association, New York, New York (ERIC Document Reproduction Service No. ED211866)

Mirels, H. L. (1970). Dimensions of internal versus external control. Journal of Consulting and Clinical Psychology. 33: 654-660.

Neel, L. S. (1979). The relationships among career maturity, locus of control, socioeconomic status, race and sex of a sample of college freshmen at three universities. Dissertations Abstracts International, 39, 4012A (University Microfilms No. 7903716).

Neugarten, Bernice (1975). Middle Age and Aging: A Reader in Social Psychology. Chicago:University of Chicago Press.

$$
\text { (1990, January 8). Periscope. }
$$

Special 90's Extravangza: Education. Newsweek. pp 5.

Norwicki, S. and Walker, C. (1973). The role of generalized and specific expectancies in determining academic achievement. Atlanta: Emory University. (ERIC Document Reproduction Service No. ED085075).

Otten M. W. (1977). Inventory and expressive measures of locus of control and Academic performance: A five-year outcome study. Journal of Personality Assessment, XL, 6, 644-49.

Patterson, M. and Sells, L. (1973). Women Dropouts from Higher Education. American Women on the Move, eds. Alice S. Rossi and Ann Calderwood. New York: Russell Sage Foundation.

Phares, E. Jerry. (December,1968). Differential utilization of information as a function of internal-external control. Journal of Personality, XXXVI, 649-62.

Plant, Walter T. and Telford, Charles W. (August, 1966). Changes in personality for groups completing different amounts of college over two years. Genetic Psychology Monographs, 74, 3-36. 
Reid, David W. and Ware, Edward E. (April,1974). Multidimensionality of internal versus external control: Addition of a third dimension and non-distinction of self versus others. Canadian Joumal of Behavioural Science, 6, 2, 131-142.

Roemer, R. E. (1983) Changing patterns of degree selection among women: 1970-78. Research in Higher Education 18 (2) : 435-454.

Rotter, J.B. and R.C. Mulry. (1965). Internal versus external control of reinforcements and decision time. Journal of Personality and Social Psychology, II, (4), 598-604.

Safilios- Rothschild, C. (1979). Sex role socialization and sex discrimination: A synthesis and critique of the literature.

Washington, D. C.: National Institute of Education,

Schegel, Ronald P., and Craig A. Crawford. (1978). Multidimensional locus of Control and drug use among high school students. Canadian Journal of Behavioural Science, X, 2, 149.

Seeman, Melvin (November, 1963). Alienation and social learning in a reformatory. The American Journal of Sociology, LXIX : 270-84.

Stack, Shirley Leon. (1981). The relationship between locus of control and perceived obstacles in graduate school for female students. Dissertations Abstracts International. 42. 752B (University Microfilms No. 8116174)

Stansbury, J. C. (1977). Maturity of vocational attitudes and locus of control as dimensions of vocational personality types. Dissertations Abstracts International, 37. 4147A (University Microfilms No. 7630026)

Turcotte, R. B. (1983) Enrollment management at the graduate level. The Journal of College Admissions, 27: 24 - 28

Zelazek, John R. (1986). Learning styles, gender, and life cycle stage: Relationships with respect to graduate students. (ERIC Document Reproduction Service No. ED276371) 